\title{
Tropical fruits and by-products as a potential source of bioactive polysaccharides
}

\author{
Frutas tropicales y subproductos como fuente potencial de polisacáridos bioactivos
}

\begin{abstract}
Salma Alejandra Enríquez-Valencia ${ }^{a}$, Gustavo A. Gonzalez-Aguilara ${ }^{\mathrm{a}}$, Leticia X. López- Martínez ${ }^{\mathrm{b} *}$
Coordinación de Alimentos de Origen Vegetal, Centro de Investigación en Alimentación y Desarrollo, A. C. Col. La Victoria, Hermosillo, Sonora, 83304, México. Coordinación de Alimentos de Origen Vegetal, Centro de Investigación en Alimentación y Desarrollo, A. C. Col. La Victoria, Hermosillo, Sonora, 83304, México.

b Cátedras CONACYT-Centro de Investigación en Alimentación y Desarrollo A. C., Carretera Gustavo Enrique Astiazarán Rosas No. 46, Col. La Victoria, Hermosillo, Sonora, 83304, México.
\end{abstract}

\section{ABSTRACT}

Consumption of tropical fruits is growing around the world, not only due to their flavor and appearance but also for their nutritional value. In addition to the content in macro and micronutrients, tropical fruits contain substantial amounts of bioactive compounds in peels and seeds, which constitute an underexploited source of bioactive compounds such as phenolic acid, polyphenols, carotenoids, vitamin C and polysaccharides. Polysaccharides have attracted growing interest, particularly for their bioactive characteristics such as antioxidants as well as antiinflammatory, antimicrobial, anticoagulant, hepatoprotective and immunomodulatory properties. Therefore, obtaining functional ingredients from tropical fruits and by-products is feasible, and could be used to develop functional and nutraceutical foods to elaborate products of the pharmaceutical industry and food preservation. The present review provides the most relevant information published the last ten years (2010-2020) on bioactive polysaccharides extracted with hot water reported in tropical fruits and by-products and their relationship with potential beneficial health effects.

Keywords: By-products, tropical fruits, polysaccharides, bioactive properties.

\section{RESUMEN}

El consumo de frutas tropicales está creciendo en todo el mundo, no solo por su sabor y apariencia, sino también por su valor nutricional. Además del contenido en macro y micronutrientes, las frutas tropicales contienen cantidades sustanciales de compuestos bioactivos en cáscaras y semillas, que constituyen una fuente subexplotada de compuestos bioactivos como ácido fenólico, polifenoles, carotenoides, vitamina $\mathrm{C}$ y polisacáridos. Los polisacáridos han atraído un interés creciente, especialmente por sus características bioactivas como antioxidantes y propiedades antihipoglucemiantes, antiinflamatorias, antimicrobianas, anticoagulantes, hepatoprotectoras e inmunomoduladoras. Por tanto, la obtención de ingredientes funcionales a partir de frutas tropicales y subproductos es factible y podría utilizarse para desarrollar alimentos funcionales y nutracéuticos para elaborar productos de la industria farmacéutica y conservación de

*Autor para correspondencia: Leticia X. López Martínez

Correo electrónico: leticia.lopez@ciad.mx

Recibido: 1 de marzo de 2021

Aceptado: 4 de agosto de 2021 alimentos. La presente revisión proporciona la información más relevante publicada durante los últimos diez años (20102020) sobre polisacáridos bioactivos extraídos con agua caliente reportados en frutas tropicales y subproductos y su relación con posibles efectos beneficiosos para la salud.

Palabras clave: Subproductos, frutas tropicales, polisacáridos, propiedades bioactivas.

\section{INTRODUCTION}

Tropical fruits grow in tropical or subtropical climates in the geographic zone that extends from $30^{\circ}$ south latitude up to $30^{\circ}$ north latitude. The temperature in this area varies between 16 to $36^{\circ} \mathrm{C}$ during the year (Dembitsky et al., 2011). The Food and Agriculture Organization (FAO) of the United Nations, estimated in 2018 that the world production of the main tropical fruits reached around 100 million tons, with an estimated increase of $3.3 \%$ expected by the end of 2020 .

The most widely consumed tropical fruits, such as avocado (Persea americana), mango (Mangifera indica), papaya (Carica papaya) and pineapple (Ananas comosus), have reached significant commercial success. They are available practically all year in areas with temperate climates (FAO, 2018). Other fruits such as açaí (Euterpe oleraceae), acerola (Malpighia emarginata), guava (Psidium guajava), jujube (Ziziphus jujuba), litchi (Litchi chinensis), longan (Dimocarpus longan), noni (Morinda citrifolia), passion fruit (Passiflora edulis) and pomegranate (Punica granatum), are strugling to find market sale sites since these fruits are imported from traditional producing countries. However, these fruits are increasingly in demand in international markets for their characteristic flavor, high nutrient content and variety of bioactive compounds such as phenolic acids, flavonoids, carotenoids and fiber (Enriquez-Valencia et al., 2020).

Over $50 \%$ of the global volume of tropical fruit produced each year is discarded as by-product, $42 \%$ of which is comprised of peels, rind/skin and 10\% of seeds (Cheok et al., 2018). Most of the tropical fruits have substantial amounts of mainly polysaccharides in peel, rind/skin, seeds and pulps, which possess a varied biological activity.

Polysaccharides are polymeric carbohydrate molecules composed of long chains of monosaccharide units 
bound together by glucosidic bonds that generate various structures, with different biological properties (de Jesus Raposo et al., 2015). Polysaccharides extracted from tropical fruits and sub-products have gained interest due to their numerous biological activities such as antioxidant, antifatigue, antiinflammatory, anticoagulant, hepatoprotective, immunomodulatory, antidiabetic and anticancer (Zhang et al., 2016; Sousa et al., 2018). This review discusses the most relevant information published in the 2010-2020 period from the main scientific databases, including Scopus, Science Direct, PubMed, Medline and Scielo, on polysaccharides and reported bioactivities of exotic tropical and their relationship with their potential beneficial effects on health.

\section{Hot water extraction (HWE)}

The extraction is a crucial process in polysaccharides isolation and production. Several methods have been applied to extract them from different plant sources, such as tropical fruits and by-products (Marić et al., 2018). One of the most common methods employed is hot-water extraction (HWE), consisting on the immersion of the raw material into distilled water at high temperature, and further steps such as filtration, centrifugation, precipitation, concentration, and freeze-drying to obtain crude polysaccharides. Additionally, it has been stated that extraction factors, such as temperature, time, and solvent/material ratio, significantly affect the yield of extracted polysaccharides. HWE has been used in the extraction of polysaccharides from by-products and tropical fruits such, açaí, acerola, guava, jujube, litchi, noni, passion fruit and pomegranate (Holderness et al., 2011; Joseph et al., 2012; Huang et al., 2017); the scientific names, common names and place of origin of the tropical fruits examined in this review, are shown in table 1.

\section{Structural characteristics of tropical fruit polysacchari- des and by-products}

The physicochemical and structural characteristics of polysaccharides, mainly include monosaccharide composition, molecular weight, configuration, type, and position of its glycosidic bond (Liu et al., 2015). Several polysaccharides have been isolated from tropical fruits and their by-products, by a sequence of techniques such as deproteinization and ion-exchange chromatography (IEC), that separates acidic and neutral polysaccharides applying different concentrations of salts such as $\mathrm{NaCl}$, as an eluent solution (Huang et al., 2014).

In order to separate the different molecular weight polysaccharides, methods such as high-performance liquid chromatography (HPLC), gel permeation chromatography (GPC), high-performance gel permeation chromatography (HPGPC) and size exclusion chromatography (SEC) (Li et al., 2020; Batista et al., 2020), are utilized. To determine the monosaccharide composition, Holderness et al. (2011) and Jiao et al. (2018) reported de application of gas chromatography coupled to mass spectrometry (GC-MS), HPLC, and high-performance or anion-exchange chromatography coupled with pulsed amperometry detection (HPAECPAD). After this step, polysaccharides are subsequently collected, dialyzed, concentrated and lyophilized to produce a pure polysaccharide.

Polysaccharides with various monosaccharides, chemical structures and functional groups, are analyzed with a combination of methods such as Fourier transform infrared spectroscopy (Rong et al., 2019), GC-MS (Hu et al., 2020), periodate oxidation-Smith degradation and methylation analysis (Wang et al., 2015; Rong et al., 2019) to determine the backbone structures. Nuclear magnetic resonance (NMR) is commonly used to analyze the configurations of glycoside residues of the polysaccharides. One-dimensional (1D) proton and carbon nuclear magnetic resonance spectroscopy $\left({ }^{1} \mathrm{H}\right.$ and ${ }^{13} \mathrm{C}$ NMR) have been generally employed for their structural characterization (Zhang et al., 2016).

Many different polysaccharides have been isolated from seeds, rinds, pulp and peels from tropical fruits, and the structural characterization, including monosaccharide chain, ratios of the monosaccharide compositions and molecular weight, are summarized in Table 2.

Characteristics such as sugar compositions, molecular weight, sugar backbone, ratios of the monosaccharide compositions and position of the functional groups are im-

Tabla 1. Origen, nombre científico y nombre común de las frutas tropicales de esta revisión.

Table 1. Origin, scientific and common name of the tropical fruits from this review.

\begin{tabular}{|c|c|c|c|c|}
\hline Name & Scientific name & Other names & Origin & Reference \\
\hline Açaí & Euterpe oleraceae & Naidí, azaí, acaí & North of Brazil & (de Oliveira and Schwartz, 2018) \\
\hline Acerola & Malpighiae marginata & Semeruco, cerecita & Brazil & (Prakash and Baskaran et al., 2018) \\
\hline Guava & Psidium guajava & & $\begin{array}{c}\text { Mexico, Central and South } \\
\text { America }\end{array}$ & (Chen et al., 2015) \\
\hline Jujube & Ziziphus jujube & Jujube & South and east Asia & (Hasan et al., 2014) \\
\hline Litchi & Litchichinensis & Lichi, lychee, Hong Hua & Malay Peninsula & (Soni and Agrawal, 2017) \\
\hline Longan & Dimocarpus longan & Dragon eye & China & (Lim et al., 2013) \\
\hline Noni & Morinda citrifolia & $\begin{array}{l}\text { Fruta del diablo, Indian } \\
\text { mulberry }\end{array}$ & Southeast Asia & (Carrillo-López and Yahia, 2011) \\
\hline Passion fruit & Passiflora edulis & Pasionaria, chinola & Southern Brazil & (Lim et al., 2012) \\
\hline Pomegranate & Punica granatum & & Himalayan region & (Jacob et al., 2019) \\
\hline
\end{tabular}


Tabla 2. Caracterización de polisacáridos de las frutas tropicales en esta revisión.

Table 2. Characterization of polysaccharides from tropical fruits considered in this review.

\begin{tabular}{|c|c|c|c|c|c|c|c|}
\hline Fruits & Part & $\begin{array}{c}\text { Mono } \\
\text { saccharide } \\
\text { composition }\end{array}$ & $\begin{array}{l}\text { Molar ratio } \\
\text { (\%) }\end{array}$ & $\begin{array}{l}\text { MW } \\
\text { KDa }\end{array}$ & $\begin{array}{l}\text { Backbone } \\
\text { structure }\end{array}$ & $\begin{array}{l}\text { Other } \\
\text { compounds }\end{array}$ & Reference \\
\hline Açaí & Fruit & $\begin{array}{l}\text { Fuc:Rha:Ara: } \\
\text { Gal:Glu:Xyl: } \\
\text { GalA:GluA }\end{array}$ & $\begin{array}{c}\text { 0.5:4.5:47: } \\
\text { 11.5:2.3: } \\
\text { 2.8:28.4:3 }\end{array}$ & 200 & $\begin{array}{c}\beta-(1,3) \\
\text {-linked galactan }\end{array}$ & $\begin{array}{l}\text { Protein } \\
\text { Phenolics }\end{array}$ & $\begin{array}{l}\text { (Holderness et al., } \\
\text { 2011) }\end{array}$ \\
\hline $\begin{array}{l}\text { Acerola } \\
\text { ACSW }\end{array}$ & Fruit & $\begin{array}{l}\text { UroA:Ara: } \\
\text { Gal:Xyl:Rha }\end{array}$ & $\begin{array}{l}52.2: 32.4: \\
7.2: 4.8: 3.5\end{array}$ & 75 & $\begin{array}{c}(15) \\
\text {-linked } \\
\text { a-Araf }\end{array}$ & Protein & $\begin{array}{l}\text { Klosterhoff et al., } \\
2018\end{array}$ \\
\hline $\begin{array}{l}\text { Bitter gourd } \\
\text { BP1 }\end{array}$ & Fruit & $\begin{array}{l}\text { Rha:Ara: Xyl:Man: } \\
\text { Glu:Gal }\end{array}$ & $\begin{array}{l}\text { 2.73:9.84: } \\
\text { 3.83:5.46: } \\
\text { 23.5:54.6 }\end{array}$ & 85 & ND & Purified & \multirow{2}{*}{ (Li et al., 2010) } \\
\hline BP3 & & $\begin{array}{l}\text { Rha:Ara:Xyl: } \\
\text { Man:Glu:Gal }\end{array}$ & 2.21:8.29:3.31:11.6:19.34:55.25 & 100 & ND & Purified & \\
\hline $\begin{array}{l}\text { Guava } \\
\text { GP70-3 }\end{array}$ & Fruit & $\begin{array}{l}\text { Rha:GlucA: } \\
\text { GalA:Gal: } \\
\text { Ara }\end{array}$ & ND & ND & $\begin{array}{c}(15) \\
\text {-linked } \\
\text { a-L-Ara } \\
(13) \\
\text {-linked } \\
\text { a-L-Ara }\end{array}$ & Purified & (Jiao et al., 2018) \\
\hline $\begin{array}{l}\text { Jujube } \\
\text { JPC }\end{array}$ & Fruit & $\begin{array}{l}\text { Man:Rib:GlucA: GalcA:- } \\
\text { Glu:Xyl: Gal:Ara:UroA }\end{array}$ & $\begin{array}{c}\text { 5.3:3.1:3.6: } \\
\text { 11.4:13.4:14.5:23.4: } 25.1: 25\end{array}$ & ND & ND & Protein & (Chi et al., 2015) \\
\hline \multirow[t]{2}{*}{ Litchi } & Pulp & $\begin{array}{l}\text { Rha:Ara:Xyl: } \\
\text { Man:Glu:Gal }\end{array}$ & $\begin{array}{c}\text { 0.31:5.44: } \\
71: 2.2: 66.1: 11.5\end{array}$ & 970 & ND & $\begin{array}{l}\text { Protein } \\
\text { Phenolics }\end{array}$ & $\begin{array}{l}\text { (Huang et al., } \\
\text { 2017) }\end{array}$ \\
\hline & Seeds & $\begin{array}{l}\text { Ara:Man:Glu: } \\
\text { Gal }\end{array}$ & $\begin{array}{l}\text { 6.33:3.88: } \\
\text { 10.4:1.1 }\end{array}$ & 6.70 & $\begin{array}{l}\text { 1,4-a-Glcp and } \\
\text { 1,4- } \beta \text {-Manp }\end{array}$ & Purified & (Wu et al., 2020) \\
\hline $\begin{array}{l}\text { Longan } \\
\text { LPD2 }\end{array}$ & Pulp & $\begin{array}{l}\text { Ara:Man:Glu: } \\
\text { Gal }\end{array}$ & $\begin{array}{l}0.25: 0.49: 1: \\
0.5\end{array}$ & 9640 & $\begin{array}{l}\text { (14)-ß-Glc and } \\
\text { (16)-ß-Man }\end{array}$ & Acetyl gruops & (Rong et al., 2019) \\
\hline Noni & Juice & $\begin{array}{l}\text { GalA:Gal:Ara: } \\
\text { Rha:Man }\end{array}$ & $\begin{array}{l}\text { 29.1:30.9: } \\
31: 5.4: 3.6\end{array}$ & ND & ND & Acetyl groups & $\begin{array}{l}\text { (Sousa et al., } \\
\text { 2018) }\end{array}$ \\
\hline $\begin{array}{l}\text { Pomen } \\
\text { granate } \\
\text { PSP001 }\end{array}$ & Rind & ND & ND & 110 & ß-1-3 galactop & ND & $\begin{array}{l}\text { (Joseph et al., } \\
\text { 2012) }\end{array}$ \\
\hline
\end{tabular}

ND: Not determinated; MW: Molecular weight; KDa: Kilodaltons.

Fuc: Fucose, GalA: galacturonic acid, Gal: galactose, Glu: glucose, Ara: arabinose, Ram: rhamnose; Man: mannose, Xyl: Xylose, UroA: Uronic acid, p:pyra-

nose.

portant for their biological activities (Sousa et al., 2018; Rong et al., 2019; Wu et al., 2020). It is essential to know that the natural polysaccharides in tropical fruits and by-products are not always isolated, but are conjugated with other structures such as phenolic compounds, amino acids, and proteins (Holderness et al., 2011; Klosterhoff et al., 2018) and sometimes, these conjugates of polysaccharides act as a whole in isolation, which affects their biological activities.

\section{Biological activities of fruit polysaccharides}

In recent years, polysaccharides from tropical fruits have been extensively studied for biological activities, such as antioxidant, antidiabetic, antiinflammatory, immunomodulatory, hepatoprotective, anticancer and antifatigue effects.

Antioxidant activity. Oxidative stress, generated mainly by an imbalance between the formation and removal of free radicals by the antioxidant defense, is the cause of most human ailments (Bhattacharya, 2015). The structural characteristics of polysaccharides will determine their antioxidant action mechanism, as well as the method to be used for their evaluation. In this sense, Zhang et al. (2016) isolated two water-soluble polysaccharides (P90 and GP90) from guava pulp, and at a concentration of $0.4 \mathrm{mg} / \mathrm{mL}$, the GP90 scavenging activity to inhibit DPPH radical was higher (97.3\%) than P90 (12.8\%), and the $\mathrm{EC}_{50}$ value was reported at 0.0672 and $1.621 \mathrm{mg} / \mathrm{mL}$, respectively. The differences in their antioxidant activity may be related to the presence of a protein conjugated to $\mathrm{P} 90$. It has been shown that in some occasions, the functional groups present in proteins are less sensitive to antioxidant assays (Wang et al., 2012). Litchi pulp polysaccharides have also shown a DPPH scavenging activity of $34.6 \%$ at $5 \mathrm{mg} / \mathrm{mL}$ (Gao et al., 2017). On the other hand, Li et $a l$. (2020) reported that noni polysaccharides demonstrate a concentration-dependent scavenging ability of ABTS radical, ranging from $10-75 \%$ at concentrations of $0.2-5.0 \mathrm{mg} /$ $\mathrm{mL}$ with an $\mathrm{EC}_{50}$ of $3.0 \mathrm{mg} / \mathrm{mL}$. de Sousa Sabino et al. (2020) isolated water-soluble polysaccharides from by-products of different tropical fruits and evaluated their ABTS scavenging activity at a concentration of $0.05 \mathrm{mg} / \mathrm{mL}$. The result showed 
that acerola polysaccharide presented the highest scavenging activity, decreasing in a $59 \%$ the ABTS radical, followed by polysaccharides from pineapple (55\%), passion fruit (34 $\%$ ), and mango polysaccharide with the lowest scavenging capacity (10\%) at the same concentration.

The in vivo antioxidant effects of polysaccharides from tropical fruits and by-products were also investigated. Chi et al. (2015) reported that oral administration of polysaccharide conjugates from jujube $(200 \mathrm{mg} / \mathrm{kg})$ in rats, increased the activities of the antioxidant enzymes glutathione peroxidase (GSH-Px) and superoxide dismutase (SOD) to 20.4 and 17.2 $\%$, whereas the level of malondialdehyde (MDA) decrease $31.4 \%$. In a different study, Sousa et al. (2018) reported that polysaccharide extracted from noni $(10 \mathrm{mg} / \mathrm{kg})$ stimulates glutathione-S-transferase about two-fold and decrease malondialdehyde levels about 8.2 -fold in rats with carrageenan-induced paw edema.

Immunomodulatory activity. It has been demonstrated that immunomodulatory polysaccharides can interact with the immune system, leading to the activation and triggering of several molecular and cellular events or suppressing the activity of lymphoid cells (Minzanova et al., 2018; Yin et al., 2019). In this sense, different studies have reported in vivo and in vitro immunomodulatory activities of polysaccharides from tropical fruits and by-products. Rong et al. (2019) isolated a polysaccharide (LPD2) from longan pulp. They observed that the treatment with $50 \mu \mathrm{L}$ of LPD2 at concentration of 100 $\mu \mathrm{g} / \mathrm{mL}$, increased the splenic lymphocytes by $250 \%$ and the macrophage phagocytosis by $205.1 \%$ to the control value. In other studies, longan pulp polysaccharides were evaluated at 100 and $200 \mathrm{mg} / \mathrm{kg}$, both treatments showing potent immunomodulatory properties in mice models, including enhanced DTH response, macrophage phagocytosis and $\mathrm{Co}-$ nA-stimulated splenocyte proliferation (Zhong et al., 2010). Polysaccharide (LCP50W) isolated from litchi pulp exhibited in vivo immunomodulatory activity, enhancing Natural Killers (NK) cells cytotoxicity and promoting mouse splenocytes proliferation (Huang et al., 2014).

Furthermore, LCP50W enhanced Th1 cytokine IFN- $\gamma$ secretion, reduced Th2 cytokine IL-4 secretion, and improved T-bet expression while inhibiting the GATA-3 gene expression. In addition, LCP50W promoted the cell cycle toward the $S$ phase (Jing et al., 2014). Three polysaccharides fractions (GSF1, GSF2 and GSF3) were isolated from guava seeds, and administered to mouse splenocytes and peritoneal macrophages to confirm the activity, based on changes in Th1/ Th2 and pro-inflammatory and anti-inflammatory cytokines secretion, respectively. All fractions, particularly GSF3, were found to have a Th2-inclination activity and anti-inflammatory capacity (Lin and Lin, 2020). Polysaccharides induced robust $\gamma \delta T$ cell stimulatory activity in human, mouse, and bovine PBMC cultures. Also, it was found that açaí polysaccharides were active by promoting myeloid and $\gamma \delta$ T cells activation, and when polysaccharides were delivered in vivo in mice, they induced myeloid cell recruitment and IL-12 production (Holderness et al., 2011).
Modulation of blood glucose. Modulation of blood glucose properties of the polysaccharides is mediated different ways including inhibiting a-amylase and a-glucosidase activities, improving cell dysfunction, targeting signaling pathways to improve glucose metabolism and enhance insulin action (Yuan et al., 2019).

The a-glucosidase can hydrolyze a-1,4-glycosidic bonds from non-reducing ends of polysaccharides to release glucose. The released glucose is absorbed by the small intestine into the blood, increasing the blood glucose level and aggravating type II diabetes; therefore, the inhibition of this enzyme is important to regulate blood glucose.

Several studies have reported the inhibition of this enzyme in vitro by polysaccharides of tropical fruits and by-products. For example, Zhang et al. (2016) described that the water-soluble polysaccharide (GP-90) isolated from guava pulp showed a-glucosidase inhibition with $\mathrm{IC}_{50}$ value $=2.27 \mu \mathrm{g} / \mathrm{mL}$, this value was 1379 times higher than the positive control acarbose $\left(\mathrm{IC}_{50}=3.13 \mathrm{mg} / \mathrm{mL}\right)$. Similar findings have been reported by Jiao et al. (2018) in the polysaccharide (GP70-3) from guava fruit also exhibited an important a-glucosidase inhibitory activity in vitro $\left(\mathrm{IC}_{50}=2.54 \mu \mathrm{M}\right)$, which was 1867 times higher than acarbose $\left(\mathrm{IC}_{50}=4.74 \mathrm{mM}\right)$. Also, an isolated polysaccharide from litchi seeds (LSP-W-4) exhibited inhibitory activity against mammalian (rat-intestinal acetone powder) and yeast (Saccharomyces cerevisiae) a-glucosidase, with $\mathrm{IC}_{50}$ values of 66.97 and $75.24 \mu \mathrm{M}$, respectively (Wu et al., 2020). Moreover, the oral administration of $200 \mathrm{mg} / \mathrm{kg}$ lychee polysaccharide suspension showed a glucose-lowering effect decreasing from 29.3 to $23 \mathrm{mM} / \mathrm{L}$ after 30 min administration to alloxan-induced diabetic rats (Huang et al., 2017).

Polysaccharides derived from jujube (ZSP) at 0, 200 or $400 \mathrm{mg} / \mathrm{kg}$ were administrated intragastrically to fructose treated mice with (20\% high-fructose water), which had impaired insulin sensitivity, hyperglycemia and hyperinsulinemia. Administration of ZSP at $400 \mathrm{mg} / \mathrm{kg}$ reduced the levels of glucose in serum from 9.62 to $8.42 \mathrm{mM} / \mathrm{L}$, insulin concentrations were lowered markedly from 72.73 to 44.61 $\mathrm{pmol} / \mathrm{L}$, the homeostasis model assessment for insulin resistance (HOMA-IR) score of the mice treated with 200 or 400 $\mathrm{mg} / \mathrm{kg}$ displayed a reduction of 25.3 and $31.3 \%$, compared to the control group. Also, the $\beta$-cell function values (HOMA- $\beta$ ) were reduced by 10.6 and $20.0 \%$, at 200 and $400 \mathrm{mg} / \mathrm{kg}$, respectively (Zhao et al., 2014).

The studies reported above indicated that polysaccharides from tropical fruits and by-products showed the capacity to modulate glucose on blood.

Anticancer activity. Polysaccharides isolated from fruit sources have been described to act on cancerous cells, primarily via apoptosis induction. Polysaccharides from tropical fruits act through DNA damage, disruption of mitochondrial membrane, cell cycle arrest and nitric oxide production, to kill cancer cells and prevent metastasis (Khan et al., 2020).

The antiproliferation impact of jujube polysaccharides on melanoma cells indicated a dose and time-dependent behavior. The $\mathrm{IC}_{50}$ value was $3.90 \mathrm{mg} / \mathrm{mL}$ after $24 \mathrm{~h}$ of treatment, 
and reduced to $3.36 \mathrm{mg} / \mathrm{mL}$ after $48 \mathrm{~h}$. The cell cycle assay showed that polysaccharides decreased cyclin B expression, causing the arrest of melanoma cells in the G2/M phase (Hung et al., 2012). In another study, Huang et al. (2014) showed the inhibitory effect of polysaccharides from litchi pulp on the proliferation of human liver (HepG2) and human cervical (Hela) cancer cells, of 41.4 and $26.7 \%$, at $750 \mu \mathrm{g} /$ $\mathrm{mL}$, respectively, while the growth of human lung epithelial (A549) cancer cells decreased $27.2 \%$ at $450 \mu \mathrm{g} / \mathrm{mL}$.

Polysaccharide (PSP001) isolated from pomegranate was evaluated on KB (nasopharyngeal carcinoma), K562 (leukemia) and MCF-7 (breast cancer) cells, as an antineoplastic agent. The effects were observed at $72 \mathrm{~h}$ of incubation for K562 cells and MCF-7 at a concentration of $0.001 \mu \mathrm{g} / \mathrm{mL}$, with $\mathrm{IC}_{50}$ values of 52.8 and $97.21 \mu \mathrm{g} / \mathrm{mL}$. PSP001 showed its best cytotoxicity at $200 \mu \mathrm{g} / \mathrm{mL}$ against KB and MCF-7 cell lines, while in $\mathrm{K} 562$ cell line was at $1000 \mu \mathrm{g} / \mathrm{mL}$ (Joseph et al., 2012). Additionally, polysaccharides from passion fruit (PFCM) dissolved in water, were administered to mice transplanted with the Sarcoma 180 tumor into the left hind groin. A tumoral growth inhibition was observed. The oral administration of PFCM at 50 and $100 \mathrm{mg} / \mathrm{kg}$ inhibited the tumor growth by 40.5 and $48.7 \%$, respectively. The intraperitoneal administration $(10$ and $25 \mathrm{mg} / \mathrm{kg}$ ) led to tumor inhibition of 70.4 and $72.89 \%$, respectively. The author concluded that inhibition is associated with the proportion of extensive coagulative necrosis of the tumors extirpated from treated mice (Silva et al., 2012).

Antiinflammatory activities. Inflammation is a complex biological reaction of vascular tissue to detrimental stimuli, such as pathogens, damaged cells or irritants, that consists of both vascular and cellular responses (Yan-Hang and Ke-Wu, 2019). The continuous presence of inflammatory mediators such as interleukin 1-beta (1L- $\beta$ ) and tumor necrosis factor-alpha (TNF-a) can upregulate nitric oxide production and prostaglandin E2. Also, enhancing the activity, cyclooxygenase-2 (COX-2), the stimulation of inducible NO synthase (iNOS) and microsomal PGE synthase-1 (mPGES-1) expression in target cells, play a critical role in developing various significant pathologies, including colitis, atherosclerosis, chronic fatigue syndrome, cardiovascular disorders, neurodegenerative diseases, and some types of cancer (Chi et al., 2015).

Some studies have supported the anti-inflammatory activities of the polysaccharides from tropical fruits. PFPe, a polysaccharide from passion fruit, was applied on carrageenan-induced rat paw edema. Carrageenan $(50 \mu \mathrm{g} / \mathrm{paw}$ ) provoked edema that reached a maximum level after $3 \mathrm{~h}$. Intraperitoneal treatment with PFPe at doses of $0.3,1.0$ or 3.0 $\mathrm{mg} / \mathrm{kg}$, resulted in a reduction of paw edema formation at $3 \mathrm{~h}$ of $34.2,39.5$ and $60.6 \%$, respectively. However, only the treatment at $3 \mathrm{mg} / \mathrm{kg}$ could decrease the inflammatory response caused by histamine $(85.3 \%$ reduction), serotonin $(5-\mathrm{HT})$ (58\% reduction), or PGE2 (62.2\% reduction). The results indicate that PFPe administration decreases the inflammatory response by modulating the release or synthesis of serotonin and histamine by reducing neutrophil migration (Silva et al., 2015).
Yue et al. (2015) described that wild jujube polysaccharides (WJPS) alleviated inflammatory bowel disease, in mice with colitis induced by 2,4,6-trinitrobenzene sulfonic acid (TNBS). WJPS significantly decreased the severity of colitis and improved the mucosal damage in mice. Treatment with WJPS decreased the inflammatory reaction by attenuation of IL-6, IL-1 $\beta$, and TNF- $\alpha$ stimuli tests.

Batista et al. (2020) showed that polysaccharides from noni (PLS) exhibited significant anti-inflammatory activity in a rat model using acetic acid-induced colitis. Administration of PLS at $3 \mathrm{mg} / \mathrm{kg}$, reduced IL-1ß and TNF - $a$ levels in the colon $(1.61$ and $2.90 \mathrm{pg} / \mathrm{mL})$ compared to the colitis group (3.58 and $4.71 \mathrm{pg} / \mathrm{mL}$ ), respectively. Also, it inhibited the colon expression of COX-2 (0.32 COX-2/p38) compared to the colitis group (0.66 COX-2/p38). The author implies that PLS shows anti-inflammatory capacity against intestinal injury by reducing the pro-inflammatory action of cytokines, COX-2 expression and inflammatory cell infiltration in the inflamed colon.

Antifatigue effects. Fatigue is a defensive system in response to life-threatening, over exhaustion and often leads to muscle soreness, anxiety and depression. If persistent fatigue is not eliminated, it may lead to different pathologies such as aging hypertension (Zheng et al., 2010). The search for natural compounds that delay fatigue or accelerate its elimination in human beings with few side effects is continuous (Xu et al., 2013), then the study of polysaccharides is a field that is beginning . For example, Zheng et al. (2010) studied the effect of antifatigue activity from hot-water longan seed polysaccharides, administered orally to ICR male mice using a swimming test, including hepatic, serum urea nitrogen and blood lactic acid content evaluation. The results show that the polysaccharides in doses ranging from $50,100,150$ and $200 \mathrm{mg} / \mathrm{kg}$, extended swimming time from the control (650 s) to $1100,800,1250$ and $900 \mathrm{~s}$, respectively, increased hepatic glycogen in all mice except at $50 \mathrm{mg} / \mathrm{kg}$, compared with the control. All dosages decreased blood urea nitrogen and blood lactic acid but only at doses of 50 and $100 \mathrm{mg} / \mathrm{kg}$.

Other studies reported the effect of the oral administration of arabinan-rich pectin from acerola fruit (ACSW) for 28 days at doses of 50, 100 and $200 \mathrm{mg} / \mathrm{kg}$, could lengthen the swimming time, which showed a longer time to exhaustion (95, 151 and $129 \mathrm{~min}$, respectively), related to the control (53 min). Furthermore, the mitochondrial respiratory capacity of the skeletal muscle, was enhanced at $200 \mathrm{mg} / \mathrm{kg}$ (Klosterhoff et al., 2018).

Hepatoprotective activity. The administration of polysaccharides from acerola (ACP) at 200, 400 and $800 \mathrm{mg} / \mathrm{kg}$ to mice fed with high-fat diets (HFD), reduces the content of total triglycerides in the liver $(16.1,17.9$ and $44.2 \%$, respectively) and attenuation of hepatic steatosis. ACPs markedly ameliorated hepatic lesions produced by HFD feeding, showing near-normal appearance with a well-preserved cytoplasm. The authors conclude that hepatic damage decreased by 
inhibition of the sterol regulatory element-binding protein 1c (SREBP1c) pathway in mice (Hu et al., 2020).

The hepatoprotective effect of polysaccharides from guava (PG) was investigated against paracetamol-induced liver damage in rat models. The results showed that the PG administration at 200 and $400 \mathrm{mg} / \mathrm{kg}$ in the paracetamol group reverted to normal the high levels of aspartate aminotransferase and alanine aminotransferase (Alias et al., 2015). Thus, tropical fruit polysaccharides can be considered potential auxiliary foods to protect the liver from drugs or diet-related injuries.

Gastroprotective effects. Studies on tropical fruit and by-products about the gastroprotective effect of polysaccharides extracted is scarce. In this sense, rats with ethanol-induced gastrointestinal damage were orally fed with polysaccharides from acerola $(1 \mathrm{mg} / \mathrm{kg})$. The results revealed that these polysaccharides maintained GSH levels in the gastric mucosa. GSH is a molecule that shows an essential role in maintaining mucosal integrity as one of the main water-soluble antioxidants. GSH may decrease or even be depleted, due to the presence of oxidizing agents such as ethanol that stimulate an increase of free radicals in gastric tissue (de Sousa Sabino et al., 2020).

\section{CORRELATION OF STRUCTURE AND BIOLOGICAL ACTIVITY}

The biological activities of polysaccharides from tropical fruits and by-products seem to be associated with their molecular weight and chemical structures. The presence of functional groups, including sulfate or acetyl, amino acids and proteins in their chemical structures, can influence the bioactivity by affecting their charge and solubility. However, studies that establish the precise relationship of structure and biological activities in polysaccharides from tropical fruits and by-products are limited; thus, more studies that establish those relationships are necessary.

It is recognized that the polysaccharides molecular weight is directly associated with some biological activities (Wang et al., 2012; de Sousa Sabino et al., 2020), e.g., in the case of antioxidant activity, Li et al. (2020) described that high molecular weight polysaccharides displayed higher antioxidant activities, due to the high molecular weight allowed the spatial conformation of the polysaccharides to be maintained. However, Wang et al. (2016) reported that the lowest molecular weight polysaccharides showed the highest antioxidant activity, since they could include more reducing hydroxyl groups in order to scavenge free radicals. On the other hand, the uronic acid content is considered another important indicator reflecting the polysaccharides antioxidant activity. Li et al. (2020) reported that polysaccharides rich in uronic acids have higher antioxidant activities, due to the uronic acid capacity to alter the physicochemical properties and solubility of the associated polysaccharide conjugates, and therefore affect their antioxidant activities (Wang et al., 201). Other studies show that the antioxidant activities of the sulfated and acetylated derivatives are more potent than that of pure polysaccharides (Khan et al., 2020).
It has been suggested that the interaction between polysaccharides and a-glucosidase is affected by the molecular weight. Low molecular weight polysaccharides exhibited a higher inhibition capacity (Dou et al., 2015). Related to the type of inhibition, polysaccharides containing sulphate produced a mixed inhibition while the desulphated generated non-competitive inhibition (Qian et al., 2015). However, Dou et al. (2015) reported a mixed inhibition in non-sulphated polysaccharides. For anticancer activities, the presence of $\beta$-(13) linkages in the main chain of the polysaccharide are important since allow an increase in immunocompetent cells activities (Wasser, 2002). Various chemical structures have been reported for the antitumor polysaccharides in different studies, including a backbone composed of (15)-linked-Araf (Jiao et al., 2018). Also, other authors reported that low molecular weight polysaccharides exhibited stronger antiproliferative activities (Hung et al., 2012).

Polysaccharides containing sulphate groups, possess strong immunomodulatory capacity, which notably reduces when the polysaccharides are desulphated (Yi et al., 2012). Nevertheless, other authors reported that low molecular weight polysaccharides exhibited stronger immunomodulatory activity, and that the polysaccharides molecular weight might play a more critical role than sulphate content, because low molecular weight might increase the capacity of polysaccharides to identify and bind immune complexes (Yi et al., 2012). Other investigations reported that the acetyl groups played a crucial role in maintaining the high immunoregulatory activity of polysaccharides since promotes the formation of hydrophobic pockets in polysaccharides, triggering different immunostimulatory responses (Ferreira et al., 2015).

For the above mentioned, it is necessary to carry out more in-depth studies to characterize polysaccharides of tropical fruits and their by-products, and the relationship of their structure with different biological activities.

\section{CONCLUSION}

Tropical fruits and their by-products are an excellent source of bioactive compounds, including polysaccharides that have shown antioxidant, immunomodulatory, antiinflammatory, among other activities, so their application to promote beneficial health effects are promising. Therefore, polysaccharides are an alternative for new functional foods. The by-product production of these fruits is extremely high, and the seeds and skins have proven to be an important source of bioactive compounds. The preparation of new polysaccharide-based alcoholic and non-alcoholic beverages, and their use in the preparation of bakery products and pasta, can contribute to human health benefits. These benefits could improve the demand, distribution, and marketing of these tropical fruits. Therefore, it is necessary to develop additional work on the bioactivities of the polysaccharides from tropical fruits and their by-products to generate more information that allows us to develop functional foods, regarding the stability of their bioactive compounds and the benefits of their consumption. 


\section{REFERENCES}

Alias, A., Othman, F., Li, A.R., Kamaruddin, A., Yusof, R. y Hussan, F. 2015. Supplementation of Psidium guajava (Guava) fruit polysaccharide attenuates paracetamol-induced liver injury by enhancing the endogenous antioxidant activity. Sains Malaysiana. 44: 1129-1136.

Bhattacharya, Susinjan. Reactive oxygen species and cellular defense system. En: Free radicals in human health and disease. Rani V. y Yadav U.C.S. (ed.), pp 17-29. New Delhi: Springer, India

Batista, J.A., de Aguiar Magalhães, D., Sousa, S.G., dos Santos Ferreira, J., Pereira, C.M.C., do Nascimento Lima, J.V., Figueira de Albuquerque, I., Sousa Dutra Bezerra, N.L. Vieira de Brito, T., da Silva Monteiro, C.E., Franco, A.X., Di Lenardo, D., Almeida Oliveira L., J.P., de Andrade Feitosa, Monteiro de Paula, R.C., Nogueira Barros, F.C., Soares de Oliveira, J., Pereira Vasconcelos, D.F., Gomes Soares, P.M.y dos Reis Barbosa, A.L. 2020. Polysaccharides derived from Morinda citrifolia Linn reduce inflammatory markers during experimental colitis. Journal of Ethnopharmacology. 248: 112303.

Carrillo-López, A. y Yahia, E.M. 2011. Noni (Morinda citrifolia L.). En: Postharvest Biology and Technology of Tropical and Subtropical Fruits. Editor(s): Elhadi M. Yahia (ed.), pp 51-64e. Woodhead Publishing.

Chen, Y., Zhou, T., Zhang, Y., Zou, Z., Wang, F. y Xu, D. 2015. Evaluation of antioxidant and anticancer activities of guava. International Journal of Food Nutrition and Safety. 6: 1-9.

Cheok, C.Y., Mohd Adzahan, N., Abdul Rahman, R., Zainal Abedin, N.H., Hussain, N., Sulaiman, R. y Chong, G.H. 2018. Current trends of tropical fruit waste utilization. Critical Reviews in Food Science and Nutrition. 58: 335-361.

Chi, A., Kang, C., Zhang, Y., Tang, L., Guo, H., Li, H. y Zhang, K. 2015. Immunomodulating and antioxidant effects of polysaccharide conjugates from the fruits of Ziziphus Jujube on Chronic Fatigue Syndrome rats. Carbohydrate Polymers. 122: 189-196.

de Sousa Sabino, L.B., da Costa Gonzaga, M.L., de Siqueira Oliveira, L., Duarte, A.S. G., e Silva, L.M.A., de Brito, E.S., de Figueiredo, W., da Silva, M.R.L. y de Sousa, P.H.M. 2020. Polysaccharides from acerola, cashew apple, pineapple, mango, and passion fruit co-products: Structure, cytotoxicity and gastroprotective effects. Bioactive Carbohydrates and Dietary Fibre. 24: 100228.

de Jesus Raposo, M.F., De Morais, A.M.B. y De Morais, R.M.S.C. 2015. Marine polysaccharides from algae with potential biomedical applications. Marine Drugs. 13: 2967-3028.

Dembitsky, V.M., Poovarodom, S., Leontowicz, H., Leontowicz, M., Vearasilp, S., Trakhtenberg, S. y Gorinstein, S. 2011. The multiple nutrition properties of some exotic fruits: Biological activity and active metabolites. Food Research International. 44: 1671-1701.

Dou, Z., Chen, C. y Fu, X. 2019. The effect of ultrasound irradiation on the physicochemical properties and a-glucosidase inhibitory effect of blackberry fruit polysaccharide. Food Hydrocolloids. 96: 568-576.

Enriquez-Valencia, S.A., Julieta Salazar-Lopez, N.J, RoblesSanchez, M., Gonzalez-Aguilar, G.A., Fernando Ayala-Zavala, J. y Lopez-Martinez, L.X. 2020. Bioactive properties of exotic tropical fruits and their health benefits. Archivos Latinoamericanos de Nutricion, 70:205-214.

FAO. El futuro de la alimentación y la agricultura:Vías alternativas hacia el 2050. Versión resumida. [Consultado enero 2021] 2018. Disponible en: http://www.fao.org/3/CA1553ES/ ca1553es.pdf
Ferreira, S.S., Passos, C.P., Madureira, P., Vilanova, M. y Coimbra, M.A. 2015. Structure-function relationships of immunostimulatory polysaccharides: A review. Carbohydrate Polymers. 132: 378-396.

Gao, W., Lin, P., Zeng, X.A. y Brennan, M.A. 2017. Preparation, characterization and antioxidant activities of litchi (Litchi chinensis Sonn.) polysaccharides extracted by ultrahigh pressure. International Journal of Food Science \& Technology, 52: 1739-1750.

Hasan, N.M., Al Sorkhy, M.A., Al Battah, F.F. 2014. Ziziphus jujube (ennab) of the middle east, food and medicine. Unique Journal of Ayurvedic Herbal Medicine. 2: 7-14.

Holderness, J., Schepetkin, I.A., Freedman, B., Kirpotina, L.N., Quinn, M.T., Hedges, J.F. y Jutila, M.A. 2011. Polysaccharides isolated from Açaí fruit induce innate immune responses. PloS one. 6: e17301.

Hu, Y., Yin, F., Liu, Z., Xie, H., Xu, Y., Zhou, D. y Zhu, B. 2020. Acerola polysaccharides ameliorate high-fat diet-induced nonalcoholic fatty liver disease through reduction of lipogenesis and improvement of mitochondrial functions in mice. Food and Function. 11: 1037-1048.

Huang, L.L., Qiao, F., Peng, G., Yang, X.T. y Duan, X. 2017. Effect of two drying methods on antioxidant activity and hypoglycemic action of polysaccharides in three cultivars of lychee pulp. Drying Technology. 35: 1994-2001.

Huang, F., Zhang, R., Yi, Y., Tang, X., Zhang, M., Su, D., Deng, Y. y Wei, Z. 2014. Comparison of physicochemical properties and immunomodulatory activity of polysaccharides from fresh and dried litchi pulp. Molecules. 19: 3909-3925.

Hung, C.F., Hsu, B.Y., Chang, S.C. yand Chen, B.H. 2012. Antiproliferation of melanoma cells by polysaccharide isolated from Zizyphus jujuba. Nutrition. 28: 98-105.

Jacob, J., Rajiv, P., Gopalan, R. y Lakshmanaperumalsamy, P. 2019. An Overview of Phytochemical and pharmacological potentials of Punica granatum L. Pharmacognosy Journal. 11.

Jiao, Y., Hua, D., Huang, D., Zhang, Q. y Yan, C. 2018. Characterization of a new heteropolysaccharide from green guava and its application as an a-glucosidase inhibitor for the treatment of type II diabetes. Food and Function. 9: 3997-4007.

Jing, Y., Huang, L., Lv, W., Tong, H., Song, L., Hu, X. y Yu, R. 2014. Structural characterization of a novel polysaccharide from pulp tissues of Litchi chinensis and its immunomodulatory activity. Journal of Agricultural and Food Chemistry. 62: 902911.

Joseph, M.M., Aravind, S.R., Varghese, S., Mini, S. y Sreelekha, T.T. 2012. Evaluation of antioxidant, antitumor and immunomodulatory properties of polysaccharide isolated from fruit rind of Punica granatum. Molecular Medicine Reports. 5: 489-496.

Khan, T., Ali, M., Khan, A., Nisar, P., Jan, S.A., Afridi, S. y Shinwari, Z.K. 2020. Anticancer plants: A review of the active phytochemicals, applications in animal models, and regulatory aspects. Biomolecules. 10: 47.

Klosterhoff, R.R., Kanazawa, L. K., Furlanetto, A. L., Peixoto, J.V., Corso, C.R., Adami, E.R., lacomini, M., Rosalvo, T.H., Fogaça, A.A., Cadena Silva, M.S.C., Andreatini, R. y Cordeiro, L. M. 2018. Antifatigue activity of an arabinan-rich pectin from acerola (Malpighia emarginata). International Journal of Biological Macromolecules, 109: 1147-1153.

Li, J., Niu, D., Zhang, Y. y Zeng, X.A. 2020. Physicochemical properties, antioxidant and antiproliferative activities of polysaccharides from Morinda citrifolia L. (Noni) based 
on different extraction methods. International Journal of Biological Macromolecules. 150: 114-121.

Li, J., Wang, Y., Huang, J., Xu, X. y Xiang, C. 2010. Characterization of antioxidant polysaccharides in bitter gourd (Momordica charantia L.) cultivars. Journal of Food Agriculture and Environment. 8: 117-120.

Lim, T.K. 2012. Passiflora edulis. En: Edible Medicinal and NonMedicinal Plants. pp 147-165. Springer, Dordrecht.

Lin,H.C.yLin, J.Y.2020.Characterization of guava (Psidium guajava Linn) seed polysaccharides with an immunomodulatory activity. International Journal of Biological Macromolecules. 154: 511-520.

Liu, X., Luo, Y., Zha, C., Zhou, S., Liu, L. y and Zhao, L. 2015. Rheological properties of polysaccharides from longan (Dimocarpus longan Lour) fruit. International Journal of Polymer Science, 2015.

Marić, M., Grassino, A.N., Zhu, Z., Barba, F.J., Brnčić, M. y Brnčić, S.R. 2018. An overview of the traditional and innovative approaches for pectin extraction from plant food wastes and by-products: Ultrasound, microwaves, and enzymeassisted extraction. Trends in Food Science and Technology. 76: 28-37.

Minzanova, S.T., Mironov, V.F., Arkhipova, D.M., Khabibullina, A.V., Mironova, L.G., Zakirova, Y.M. y Milyukov, V.A. 2018. Biological activity and pharmacological application of pectic polysaccharides: A review. Polymers. 10: 1407.

de Oliveira, M.D.S. y Schwartz, G. 2018. Açaí-Euterpe oleracea. En Exotic Fruits Reference Guide. Rodrigues, S., Silva, E., de Brito, E. (ed.), pp. 1-5. Academic Press, Cambridge, UK.

Prakash, A. y Baskaran, R. 2018. Acerola, an untapped functional superfruit: a review on latest frontiers. Journal of Food Science and Technology. 55: 3373-3384.

Qian, J. Y., Bai, Y. Y., Tang, J. y Chen, W. 2015. Antioxidation and a-glucosidase inhibitory activities of barley polysaccharides modified with sulfation. LWT-Food Science and Technology. 64: 104-111.

Rong, Y., Yang, R., Yang, Y., Wen, Y., Liu, S., Li, C., Hu, Z., Cheng, X. y Li, W. 2019. Structural characterization of an active polysaccharide of longan and evaluation of immunological activity. Carbohydrate Polymers. 213: 247-256.

Silva, D.C., Freitas, A.L.P., Barros, F.C.N., Lins, K.O., Alves, A.P.N., Alencar, N. M., de Figueiredo, I.S.T., Pessoa, C., de Moraes, M.O., Costa-Lotufo, V., Judith P.A., Maciel, J.S, de Paula y de Paula, R.C. 2012. Polysaccharide isolated from Passiflora edulis: Characterization and antitumor properties. Carbohydrate Polymers. 87: 139-145.

Silva, R.O., Damasceno, S.R., Brito, T.V., Dias, J.M., Fontenele, A.M., Braúna, I.S., Júnior, J.S.C., Maciel, J.S., de Paula, R.C.M., Ribeiro, R., Souza, M.H.L.P., Freitas, A.L., Medeiros, J-V. R., Silva, D.C.y Barbosa, A.L. 2015. Polysaccharide fraction isolated from Passiflora edulis inhibits the inflammatory response and the oxidative stress in mice. Journal of Pharmacy and Pharmacology. 67: 1017-1027.

Soni, R. y Agrawal, S. 2017. Litchi chinensis: taxonomy, botany and its cultivars. En Lychee Disease Management. M. Kumar, V. Kumar, N. Bhalla-Sarin, A. Varma (eds) pp. 191-215. Springer, Singapore.

Sousa, S.G., Oliveira, L.A., de Aguiar Magalhães, D., de Brito, T.V., Batista, J.A., Pereira, C.M.C., de Souza Costa, M., Raposo Mazulo, J.C., de Carvalho Filgueiras, M., Pereira Vasconselos D.F., Alves da Silva, D., Nogueira Barros, F.C., Sombra, V.G.,
Ponte, A. y dos Reis Barbosa, A.L. 2018. Chemical structure and anti-inflammatory effect of polysaccharide extracted from Morinda citrifolia Linn (Noni). Carbohydrate Polymers. 197: 515-523.

Wang, Y., Yang, Z. y Wei, X. 2012. Antioxidant activities potential of tea polysaccharide fractions obtained by ultra-filtration. International Journal of Biological Macromolecules. 50: 558564.

Wang,J.,Hu, S.,Nie, S.,Yu, Q.yXie, M. 2016. Reviewson mechanisms of in vitro antioxidant activity of polysaccharides. Oxidative Medicine and Cellular Longevity, 2016.

Wasser S.P. 2020. Medicinal mushrooms as a source of antitumor and immunomodulating polysaccharides. Applied Microbiology and Biotechnology. 60: 258-274.

Wu, J., Xu, Y., Liu, X., Chen, M., Zhu, B., Wang, H., Shi, S., Qin, L. y Wang, S. 2020. Isolation and structural characterization of a non-competitive a-glucosidase inhibitory polysaccharide from the seeds of Litchi chinensis Sonn. International Journal of Biological Macromolecules. 154: 1105-1115.

Yi, Y., Zhang, M. W., Liao, S. T., Zhang, R.F., Deng, Y.Y., Wei, Z.C., Tang, X.J., y Zhang, Y. 2012. Structural features and immunomodulatory activities of polysaccharides of longan pulp. Carbohydrate Polymers. 87: 636-643.Yan-Hang, W. y Ke-Wu, Z. 2019. Natural products as a crucial source of anti-inflammatory drugs: recent trends and advancements. Traditional Medicine Research. 4:257.

Yin, M., Zhang, Y. y Li, H. 2019. Advances in research on immunoregulation of macrophages by plant polysaccharides. Frontiers in Immunology. 10: 145.

Yuan, Q., Fu, Y., Xiang, P.Y., Zhao, L., Wang, S.P., Zhang, Q., Liu, Y-T., Qin, W., Li, D-Q. y Wu, D.T. 2019. Structural characterization, antioxidant activity, and antiglycation activity of polysaccharides from different chrysanthemum teas. Royal Society of Chemistry Advances. 9: 35443-35451.

Yue, Y., Wu, S., Li, Z., Li, J., Li, X., Xiang, J. y Ding, H. 2015. Wild jujube polysaccharides protect against experimental inflammatory bowel disease by enabling enhanced intestinal barrier function. Food and Function. 6: 2568-2577.

Xu, C., Lv, J., Lo, Y. M., Cui, S. W., Hu, X. y Fan, M. 2013. Effects of oat $\beta$-glucan on endurance exercise and its antifatigue properties in trained rats. Carbohydrate Polymers. 92: 11591165.

Zhang, Z., Kong, F., Ni, H., Mo, Z., Wan, J.B., Hua, D. y Yan, C. 2016. Structural characterization, a-glucosidase inhibitory and DPPH scavenging activities of polysaccharides from guava. Carbohydrate Polymers. 144: 106-114.

Zhao, Y., Yang, X., Ren, D., Wang, D. y Xuan, Y. 2014. Preventive effects of jujube polysaccharides on fructose-induced insulin resistance and dyslipidemia in mice. Food and Function. 5: 1771-1778.

Zheng, S.Q., Jiang, F., Gao, H.Y. y Zheng, J.G. 2010. Preliminary observations on the antifatigue effects of longan (Dimocarpus longan Lour.) seed polysaccharides. Phytotherapy Research: An International Journal Devoted to Pharmacological and Toxicological Evaluation of Natural Product Derivatives. 24: 622-624.

Zhong, K., Wang, Q., He, Y. y He, X. 2010. Evaluation of radicals scavenging immunity-modulatory and antitumor activities of longan polysaccharides with ultrasonic extraction on in S180 tumor mice models. International Journal of Biological Macromolecules. 47: 356-360. 